Review scientific article Received 12.10.2017.

Approved 17.11.2017.

\title{
THE FIRST FOREIGN POLICY OUTCOMES OF IMPLEMENTING THE CHINESE BELT AND ROAD INITIATIVE IN EURASIA
}

The article poses the question of how beneficial the Chinese strategic Belt and Road Initiative (BRI) appears at its initial stage. After providing a general description of the Initiative's core principles and components, the author tries to emphasize the advantages and drawbacks of its potential implementation with a special focus on the interrelations between China and the proposed partners. Central Asia and Russia are thus put under the microscope as the neighbouring states, having no other way but to interact with China, it being the unequivocal rising economic and geopolitical power. The author examines overlapping spheres of interest of China and these countries in order to shed light on future perspectives of proclaimed "equal cooperation for all". The model of the Chinese behaviour and the country's capacity for dialogue are presented through the "EAEU-Silk Road" integration project.

Keywords: Belt and Road Initiative, Silk Road Economic Belt, infrastructure projects, cooperation, China.

North-East Asian Strategic Issues and SCO Centre, Institute of Far Eastern Studies, Russian Academy of Sciences, Moscow, Russia; kulintsev.y@ifes-ras.ru 


\section{Introduction}

As soon as the Silk Road Economic Belt concept was officially introduced in 2013 , it started to draw the international community's attention. We witnessed a surge in China's foreign policy and an evident global change of its role. The progress resulted from its economic growth and the altered geopolitical situation in the Asia-Pacific region.

At the pivotal historic moment, a new generation of Chinese leaders headed by Xi Jinping found itself confronted with the new challenges, such as general slowdown in the global economic growth, the rising rivalry of the world powers in Asia and the deterioration of external relations with a number of neighbouring countries.

China's leading position in terms of international trade and economic relations resulted in Beijing's dependence on energy imports and sea trade routes. Amid the growing complexity of multilateral international relations, which were getting even more ambiguous, the political leadership had to look for an adequate response to the new challenges. These challenges could have endangered economic and foreign policy stability of China as the rising power.

While staying in Kazakhstan during a working tour around the Central Asian countries in September 2013, the President of the People's Republic of China, Xi Jinping introduced an initiative to jointly build the Silk Road Economic Belt. ${ }^{1}$ One month later during the state visit to Indonesia, the Chinese leader proposed the idea of the 21st- Century Maritime Silk Road. It was supplemented by the concept of establishing the Asian Infrastructure Investment Bank (AIIB). ${ }^{2}$ Both initiatives caused hot debates in political and academic circles. The initial elaboration of the projects at the expert level took about one year and a half, and it has started to take a concrete shape.

The first official document regarding the Belt and Road Initiative (BRI) was presented in March 2015 during the annual conference of the Boao Forum for Asia (BFA). It contained the description of the principles, structure, priority guidelines and mechanisms of collaboration of the project. The document was issued by the National Development and Reform Commission, the Ministry of Foreign Affairs and the Ministry of Commerce of the People's Republic of China and was named "Vision and Actions on Jointly Building Silk Road Economic Belt and 21st- Century Maritime Silk Road". ${ }^{3}$ The goal of the large-scale project is the creation of a new mechanism for economic development that would provide a

1 "Xi Jinping offered to create "Silk Road Economic Belt", The Xinhua news, 07.09.2013, http://www.russian.news.cn/china/2013-09/07/c_132700806.htm (20.08.2017).

2 "Jointly build a New Maritime Silk Road" , The Xinhua news, 4.10.2013, http://www. russian.news.cn/china/2013-10/04/c_132771322.htm (20.08.2017).

3 National Development and Reform Commission, the Ministry of Foreign Affairs and the Ministry of Commerce of the People's Republic of China: "Vision and Actions on Jointly Building Silk Road Economic Belt and 21st-Century Maritime Silk Road", 28.03.2015, 
more effective resource allocation and strengthen market integration between the states of Asia, Europe and Africa. The infrastructure projects are going to unite more than 65 countries located along the Ancient Silk Road.

The idea of the 21st-Century Maritime Silk Road implies building of two routes. One of them will connect China's coast and Europe through the South China Sea and the Indian Ocean, and the other will stretch from China's coast to the South Pacific, again through the South China Sea - a geographical object turning into one of the key zones of the maritime project. In 2009 China demonstrated its readiness to stand firm for its geopolitical and economic interests in the water area, having declared the sovereignty of the major part of the South China Sea. ${ }^{4}$

In this paper the author argues that the Silk Road Economic Belt is a largescale geopolitical project aimed at developing the region of the Western China as well as expanding its links with foreign countries, in particular, the countries in Central Asia. According to the published documents, the Silk Road Economic Belt presupposes the construction of the Eurasian land bridge to link China and Europe through Russia and the Central Asian states with the final destination at the Baltic Sea; China with the Persian Gulf and the Mediterranean Sea through Central Asia and West Asia; China with Southeast Asia, South Asia and the Indian Ocean. It is also planned to form economic corridors "China-Mongolia - Russia" (the agreement signed in 2016) ${ }^{5}$, "China - Central Asia - West Asia", "China - Indochina Peninsula", "China - Pakistan" (the documents on the construction of infrastructure facilities signed in 2015)" "Bangladesh - China India - Myanmar"?

\section{Political meaning of BRI}

The importance of the above-mentioned document "Vision and Actions" is acknowledged due to the fact that it provides a definition of five basic components of cooperation in the Belt and Road Initiative project. The

NDRC official website, http://en.ndrc.gov.cn/newsrelease/201503/t20150330_669367.html (29.11. 2015).

4 D.Mosyakov: "Chinese politics in the South-China Sea", Perspective, 16.01.2014, http:// www.perspektivy.info/history/na_grani_fola_politika_kitaja_v_juzhno-kitajskom_ more_2014-01-16.htm (20.08.2017).

5 K.Latukhina: "Russia, China and Mongolia will create an economic corridor", The Russian Newspaper, 23.06.2016, https://rg.ru/2016/06/23/rossiia-kitaj-i-mongoliia-sozdadutekonomicheskij-koridor.html (20.08.2017).

6 N.Zamaraeva: "China-Pakistan economic corridor and position of India”, The East Analytics, 25.03.2017, http://va.ivran.ru/articles?artid=7258 (20.08.2017).

7 Reference materials: “One Belt, One Road", The RIA News, 16.07.2017, https://ria.ru/ spravka/20170514/1494097368.html (20.08.2017). 
construction of a single transport network, promotion of trade and investment liberalization, industrial cooperation as well as humanitarian exchanges and contacts are expected to become cooperation priorities. The following things will be established according to the document:

Policy coordination means a permanent exchange of the opinions on diverse issues of economic development strategies. The strategies are going to introduce the measures and programs of economic integration. The main task is to pave the way for the emergence of regional economies, streamlining of customs, visa and other procedures at political and juridical levels for the sake of entrepreneurial activities (conducted by the regional states or China) and the expansion of collaboration.

Facilities connectivity includes the construction of a single transport infrastructure from the Pacific Ocean to the Baltic Sea. China is ready to take part in building a transnational transport infrastructure, forming a transport network that would cover Central, East, West and South Asia. The creation of transportlogistical infrastructure will enable a delivery of goods (primarily the Chinese ones) to the markets of Central Asia, Russia, Europe, and the Middle East.

Unimpeded trade stands for the expansion of trade links and elimination of any impeding bureaucratic and judicial barriers, for speeding up delivery of goods and the creation of a corresponding logistical system. The increase in volume of mutual trade is going to accelerate the process of coordinating projects in free trade zones in Uzbekistan and Kyrgyzstan and stimulate mutual trade with all the regional states.

Financial integration means the intensification of currency flows. Currently, China trades successfully with a number of states (Russia, for instance) in national currencies rather than in dollars. This experience is to be transmitted to Kazakhstan and other countries of Central Asia to reduce transaction costs, protect the financial system from risks and raise international competitiveness of the economy. The enhancement of trade in national currencies will help turn yuan into the regional currency, thus being able to conquer dollar and euro as the payment leaders.

Finally, people-to-people bond will encourage the links between people. The relations between countries depend on how close the ties between the nations are. Regional cooperation is going to gain support from all the people, foster people-to-people exchanges and contribute to better mutual understanding and traditional friendship. Consequently, all these things are going to develop regional collaboration. The expansion of contacts in scientific and technical, educational and humanitarian spheres is one of the cooperation aims. It presupposes the increase in the number of foreign students from the BRI region to study at Chinese universities. Therefore, in this way Chinese culture is going to expand across its national borders and, secondly, assume greater significance in terms of soft power in new leaders' foreign policy. 
Focusing attention on these aspects, Beijing refers to these models as "new models of international cooperation" and invites others to take part in the joint endeavour and form the Silk Road Economic Belt.

\section{Establishing financial cooperation}

The concrete measures of the projects' implementation will comprise several interconnected steps. The enormous financial opportunities will stem from infrastructure construction: build-up of automobile and railway roads, transportation pipelines and power lines, bridges and ports. The experts of the Asian Development Bank expect that by 2020 this sphere will have demanded investments no less than $\$ 8$ trillion. ${ }^{8}$

It is mentioned in the document that the project, open for each and every country, international and regional organizations, will provide a significant inclusive platform for uniting the Chinese economy and interests of the states involved. During the Boao Forum for Asia 2015 the PRC President Xi Jinping said: "Belt and Road is not China's solo but inspiring chorus of all the countries along the routes". ${ }^{9}$ China is ready to improve the initiative's concept hand in hand with other countries, to work out projects' schedule and the multisided formats of the cooperation as well as equal negotiations over international issues.

The authors of the concept made an effort to present a detailed action plan on almost all the aspects of economic interactions. This is quite a complicated task, as the project embraces several dozens of states comprising $60 \%$ of the world population. From 2014 to 2016 the volume of economic activities between China and the countries along the Silk Road Economic Belt exceeded $\$ 3$ trillion. ${ }^{10}$ The cooperation suggests establishing multilevel platforms and conducting multisided consultations, conclusion of memoranda of understanding, elaboration of joint road maps and launching of bilateral pilot projects. It is also supposed to use the capacities of the existing bilateral mechanisms of interaction - joint committees, commissions and coordination groups, with the participation of China and other actors, primarily, neighbouring states. In order to strengthen "communication factor" of collaboration and attract new countries, it is expected to use the full potential of the existing international platforms - the Shanghai Cooperation Organization (SCO), ASEAN plus $1(10+1)$, APEC, Asia-Europe Meeting, the Conference on Interaction and Confidence Building Measures in Asia (CICA),

$8 \quad$ S.Gafurov: "China tries to change the world's financial system", The VZGLYAD business newspaper, 14.01.2015, https://vz.ru/economy/2015/4/14/739927.html (20.08.2017.).

$9 \quad$ "Chinese President Xi Jinping's keynote speech during the opening ceremony of the Boao Forum for Asia (BFA) Annual Conference 2015 in Boao", The Xinhua news, 28.03.2015, http://news.xinhuanet.com/english/2015-03/28/c_134105208.htm (20.08.2017).

10 "Chinese President Xi Jinping's speech during BRI Forum (Beijing)", The Xinhua news, 14.05.2017, http://finance.ifeng.com/a/20170514/15373505_0.shtml (20.08.2017). 
CAREC. International exhibitions and forums at regional and sub regional levels also have their major role.

The Chinese initiative, reflecting the ideals and values of the humankind, is a trial to seek a new model of the international interaction that will give a positive impetus to the global development and will provide maintenance of peace on the planet. China does not strive for economic hegemony, nor does it want to proclaim its exceptionalism. Theoretic background of the concept coincides with the key goals of the UN Charter and "five principles of peaceful coexistence". "The Project is fully open for the participation of all the members of the international community and does not limit its boundaries to the territory of the Ancient Silk Road. ${ }^{12}$

The document "Vision and actions on jointly building Silk Road Economic Belt and 21st-Century Maritime Silk Road" clearly states principles and structure of the future "entity", priorities and mechanisms of proposed cooperation. ${ }^{13}$ However, it lacks the description of concrete projects, except for AIIB, Silk Road Fund and several affairs in the humanitarian sphere such as Silk Road International Film Festival and Silk Road International Book Fair. Even this caused certain disillusionment of the expert community. The general explanation for absent qualitative parameters is that the term "vision" implies a reflection of the basic ideas and vectors.

The analysis of the Chinese variant of forming "Belt and Road" indicates that China hopes to increase the scale of its openness to the external world and foster mutually beneficial cooperation with the member-states through the project's implementation. Moreover, the realization of geopolitical goals also has a considerable impact: China takes on more political commitments and international responsibilities according to its economic capacities. According to the general provisions of the concept, the country is ready to substantially contribute to the humankind development.

11 Agreement on trade and intercourse between Tibet Region of China and India, United Nations Treaty Series, vol. 299, pp. 57-81, 29.04.1954, http://treaties.un.org/doc/ publication/unts/volume\%20299/v299.pdf (20.08.2017).

12 Y.Kulintsev: "One Belt, One Road - initiative with Chinese characteristics", The Russian International Affairs Council, 22.05.2015, http://russiancouncil.ru/blogs/ riacexperts/?id_4=1868 (20.08.2017).

13 National Development and Reform Commission, the Ministry of Foreign Affairs and the Ministry of Commerce of the People's Republic of China: "Vision and actions on jointly building Silk Road Economic Belt and 21st-Century Maritime Silk Road", 28.03.2015, NDRC official website, http://en.ndrc.gov.cn/newsrelease/201503/t20150330_669367.html (29.11. 2015). 


\section{Geopolitical risks for China and Eurasia}

It is worthwhile noting that there are significant challenges and risks emerging during the initiative's implementation. The development of transport lines and the creation of a high-speed transport corridor for the Chinese cargo transit to Europe can lead to the workload reduction of the Russian TransSiberian railway and Baikal-Amur Mainline. The focus on the development of raw materials projects can cause complete economic dependence on a financially firmer partner on behalf of other cooperating states.

A serious challenge for China during the implementation of the Belt and Road Initiative is forging geopolitical relations with the Central Asian countries and Russia. Central Asia is a specific region marked by intermingling interests and discords between Russia, the USA, Europe, China, India, Iran, and Turkey, on the one hand, and between the regional states, on the other. That is why China is going to put in considerable effort to moderate these relations and tensions as the spearhead of a new integration project.

Cultural and mental differences among the member-states of the project pose definite risks to China, especially due to the fact that the number of these countries amounts to several dozens. The only Chinese factor that can consolidate such diverse actors is its lending capacity.

One of the challenges for Russia and regional states is the very absence of specificities of the project.

A list of infrastructure projects agreed upon in 2017 in the context of integrating EAEU and the Silk Road Economic Belt has not been still entirely published. What is known for certain is that projects will relate to the construction of new roads and the modernization of the existing roads, the establishment of transport and logistics centres, and the development of key transport hubs. ${ }^{14}$ As a result, it is not clear what Silk Road can offer apart from transport, trade and financial infrastructure. To address these concerns Beijing needs to suggest detailed breakthrough projects such as the well-known "Central Asia-China Gas Pipeline Network". Nevertheless, it will be problematic as China counts mostly on the cooperation in the energy sector, the provision of favourable loans and the delivery of commodities.

Meanwhile, it is necessary to understand that along with the deals in energy sector and the creation of transport corridors, China's interest implies the acquisition of foreign assets. Beijing simultaneously plans to shift production facilities to the neighbouring countries and has already turned into the leading lender for a number of states. Taking into consideration the Chinese tactics of exporting labour force to the zones of infrastructure projects' realization,

14 "A list of infrastructure projects for EAEU and the Silk Road Economic Belt integration", Eurasian Economic Union official website, 02.03.2017. http://www.eurasiancommission. org/ru/nae/news/Pages/2-03-2017-1.aspx (20.08.2017). 
it seems that the transport projects will help not only gain control over the goods, services, capitals and labour flows, but also expand its demographic and, correspondently, geopolitical presence in this or that country.

For these reasons, the analysis of national interests of the regional states should be conducted before they submerge in the implementation of the Chinese projects. Each initiative will be considered from the angle of technical and commercial assessment, examined through marketing researches on the subject of demands and potential of national economies along with the following risks that may occur.

Central Asia is the epicentre of the world powers' collisions. Diverse concepts of the region development have already been offered by the members of the Eurasian Economic Union, China and the USA. ${ }^{15}$ The direction of the world economic development in the forthcoming decade will depend on which of these concepts will be chosen. Currently, China's initiative looks more feasible than the others.

\section{Chinese model of BRI implementation}

The structural component of the Chinese project can be beneficial for all the participants. The Chinese government is ready to guarantee multisided openness, stimulate practical interaction in all spheres and, hence, form the "community of shared destiny". Even the keynote address made by President Xi Jinping during the 2015 annual conference of the Boao Forum for Asia was named "Towards a Community of Common Destiny and a New Future for Asia". ${ }^{16}$ It will be perceived with a due seriousness, as the speeches delivered by the PRC President never contain random terms. The point announced will come true to life sooner or later. The question "when" - is a matter of secondary importance.

The countries located in the area of the Belt and Road possess unique resources, their economic bases complement each other and this cooperation has an enormous space for development. This statement is almost unquestionable, although we are fully aware that some countries will benefit more from this interaction. As for Russia, its participation may lead to infrastructure improvement, further diversification of energy delivery routes and strengthening of investment cooperation with China. The Central Asian states have huge transit potential. Kazakhstan may become an optimal land transport hub in the European-Russian-Chinese Chain due to its geographical location right in the

15 "EAEU, China, US - who is winning Central Asian strategy?", Eurasian Communication Center, 21.11.2014, www.eurasiancenter.ru/infrastructure/20141121/1003776366.html (20.08.2017).

16 "Boao Forum for Asia: the main attention on the community of shared destiny and BRI", The People's Daily, 30.03.2015, http://russian.people.com.cn/n/2015/0330/c95181-8871312. html (20.08.2017). 
centre of Eurasia. Uzbekistan may transform into a large logistical centre for cargo flow from Turkmenistan, Afghanistan, Iran and succeed in generating the income from cargo traffic. Beijing may strengthen its position in Central Asia and serve as the final destination for cargo carriage from South-East Asia to Europe. Additionally, China possesses vast financial resources.

In the modern world, economic development is directly shaped by investments. Pragmatically oriented China initiated the establishment of the Asian Infrastructure Investment Bank (AIIB) ${ }^{17}$ in 2013 to allocate finances for regional projects. Not surprisingly, the details of the Belt and Road Initiative were revealed just three days before the closure of the application procedure for joining this financial organization. Despite the expectations of some pundits, Russia announced its intention to enter AIIB at the last minute after more than 50 other countries had already joined. ${ }^{18}$

The decision to create AIIB and the Silk Road Fund has already proved to be successful. The leading countries of West Europe such as Germany, France, Italy and the UK also joined AIIB, the share capital amounts to $\$ 100$ billion. $\$ 10$ billion out of $\$ 40$ billion of the Fund's share capital will be distributed for the existing projects.

It is necessary to mention that over the last couple of years, since the announcement of the strategic initiative by Xi Jinping, the Chinese government has been actively vitalizing its grand project. The leaders of foreign countries and representatives of international forums discussed the concept. Having signed the memoranda of understanding, the plans of economic interaction were coordinated, and the communication support on priority spheres of cooperation provided.

By 2017 the BRI was backed up by more than 100 countries and international organizations. About 40 states and international organizations signed the memoranda of understanding. ${ }^{19}$ In May 2015 the leaders of Russia and China signed the Joint Statement on Cooperation on the Construction of Joint Eurasian Economic Union and the Silk Road Economic Belt projects. ${ }^{20}$ In 2016 Kazakhstan approved integrating its national development program "Nurly Zhol" with the Chinese Silk Road Economic Belt. ${ }^{21}$ After the Russian-Chinese-Mongolian

17 “An Asian infrastructure bank. Only connect", The Economist, 04.10.2013, http://www. economist.com/blogs/analects/2013/10/asian-infrastructure-bank-1 (20.08.2017.).

18 "China-led AIIB attracts rush of applicants", The Financial Times, https://www.ft.com/ content/94728d96-d82f-11e4-ba53-00144feab7de_(20.08.2017).

19 Reference materials: “The strategy of economic development - One Belt, One Road", The RIA News, 14.05.2017, https://ria.ru/spravka/20170514/1494097368.html (20.08.2017).

20 Joint Statement of Russian Federation and People's Republic of China on Cooperation on the Construction of Joint Eurasian Economic Union and the Silk Road Economic Belt projects, The Kremlin, 08.05.2017. http://www.kremlin.ru/supplement/4971 (20.08.2017.).

21 O.Sukhareva: "Silk Road - unopposed north route", The Rhythm of Eurasia, 30.06.2016, https://www.ritmeurasia.org/news--2016-06-30--shelkovyj-put-bezalternativnostsevernogo-marshruta-24422 (20.08.2017). 
negotiations in the summer of 2016 on the sidelines of SCO meeting in Tashkent, the countries signed up the program of the trilateral economic corridor to include more than 30 potential projects. In addition, the states adjusted the terms of the construction. $^{22}$

The international forum held in May 2017 became a landmark event in the evolution of the BRI realization. Preceded by a row of expert meetings and consultations on different aspects of Silk Road, it gathered more than 1500 participants from 130 countries. ${ }^{23}$ It was also marked by the PRC President's address to the global leaders that they should be against protectionism and stand for globalization. This successful global long-term strategy appears to be the reason for both going down in history and staying at Presidential office for one more term.

According to the schedule that was ordered during the Forum, the next high-level meeting on the same agenda will take place in two years. In the $1^{\text {st }}$ Forum China's ambition for a more principal role in defining the rules of the game on the global arena was noticeable.

\section{Conclusion}

The idea of the Silk Road Economic Belt has a firm cultural and civilizational background: a reference to the historic role of the participating states of the Ancient Silk Road serves as the meaningful uniting factor for the economically and politically diverse countries such as China, Pakistan, the Central Asian states. In this sense, China performs as an economic and "ideology" leader offering its solutions to the regional problems.

The Chinese Belt and Road Initiative is a long-term project aimed at promoting the integration of a "non-aligning" (to the blocks) character of the Chinese foreign policy. It does not create an alliance against a country or a group of states. From the point of economic relations, it provides transparency and openness. China is ready to combine this initiative with the development strategies of other parties and it is willing to accord it with the existing regional mechanisms of cooperation.

The Chinese Silk Road Economic Belt is a vital initiative having socioeconomic, political and diplomatic, cultural, civilizational and geopolitical aspects. Its purpose is to ensure the Chinese interests especially near the sovereign borders, and even further, if possible.

22 K.Latukhina: "Russia, China and Mongolia will create an economic corridor", The Russian Newspaper, 23.06.2016, https://rg.ru/2016/06/23/rossiia-kitaj-i-mongoliia-sozdadutekonomicheskij-koridor.html (20.08.2017).

23 "A high level "OBOR" Forum has been opened in Beijing”, The RIA News, 14.05.2017. https://ria.ru/world/20170514/1494250680.html (20.08.2017.). 
Economically, China aims to provide its economy with raw materials, manufactured goods, marketing outlets, workforce and jobs. Since China lacks these components, going "outwards" is the only solution to the problem.

The political interest of China is maintaining security on the Eurasian space. The Silk Road project is all about developing trade and economic relations of China with regional partners through the assistance to the economic development of the latter. This is vital for the preservation of a stable political situation in these states. Geopolitically speaking, China reacts to the American and the West European policies that undermine stability in the neighbouring regions, aim to control China's economic growth and restrict its rising influence in the world.

It is essential for Russia and the Central Asian states to understand that China's influence in the near future is unavoidable. Therefore, these countries should consider this situation. Chinese interests overlap with the ones of Russia and Central Asia, which makes the collaboration even more reasonable. These national actors along with China are concerned about economic development and political stability (in particular, amid terror threats that may emerge in their territories; for China - the matter of Xinjiang). Moreover, China does not demand from the states their political commitment for the sake of trade and economic cooperation; therefore, it performs as a stronghold resisting the Western attempts of overthrowing political regimes. Their attempts could only harm security and political stability. The Chinese declarations about the complete correspondence of national interests to the partners' strategies are not always demonstrated in practice. Thus, while making investments China may insist on the use of its national technologies and workforce while not obeying local environmental legislation and so on. These questions may be regulated and the Chinese companies and state structures are ready to have a dialogue and listen to the arguments of their partners.

China's readiness for the dialogue is the approval of EAEU and the Silk Road Economic Belt integration by China. Despite the negative assessments made by a number of Chinese experts, the country's leadership settled for a compromise and accepted the idea of integration. We may assume that it happened thanks to the right perception of Russia's arguments about larger perspectives of collaboration with a single custom space rather than separate actors.

Beijing demonstrates interest in the Russian suggestion of "differentiation of labour". It presupposes that Russia will deal with security issues, EAEU with the legislative basis of cooperation, and China with infrastructure and development investments. In the current geopolitical context China needs Russia's support and the Eurasian integration.

As for Russia, the state looking forward to creating "Big Eurasia", the enforcement of the Eurasian Economic Union and the development of relations with China can be of tremendous importance. Successful implementation 
of these two tracks will help Russia face the sanctions, gain the role of an independent centre of world politics and ensure modernized growth and socioeconomic development of its Eastern regions. Hence, the value of the integration initiative can hardly be overestimated.

Simultaneously, Russia will manage to preserve its political influence and economic role in Central Asia. The most promising tactics in this regard may be searching for the junction points between BRI, EAEU and SCO. Other regional actors participating in the project will have to evaluate cooperation from the "equality" aspect.

Russia and the Central Asian states are to avail themselves of the whole situation as well as use China's commitment to cooperation and its considerable potential for their personal interests. It is urgent to propose a joint EAEU initiative regarding the concept of integration with infrastructure and other projects. Hopefully, this concept can have a complex and systematically shaped form at political and public levels. It will distinctly state the vision of Russia and its partners of the region and the mechanisms of managing real projects. Unfortunately, these ideas and concepts are not typical of modern Russia.

To optimize the Russian political resource for economic projects' stimulation, the country needs to boost the activity of the Shanghai Cooperation Organization and focus on the coordination of economic cooperation (EAEU and Silk Road) without earlier involved states of Central Asia and the giants such as India, Pakistan, Iran, Mongolia and other members and observers of the SCO.

For the international community, the Belt and Road Initiative may herald a start of a new financial world order. The successful launch of the Asian Infrastructure Investment Bank will allow the most dynamically developing states of Asia to attract investments from the financial institution that will not coerce into following the pro-Western models of development. As a result, the International Monetary Fund and the World Bank that used to bring financial advantage to the West may lose their significance. Effective implementation of the Chinese project will become one of the determining factors. It is going to forge international relations of a new type, with "cooperation" and "benefits for all" principles at the core of a new financial architecture. 


\section{Literature}

- Gafurov, S. (2015): China tries to change the world's financial system, VZGLYAD, https://vz.ru/economy/2015/4/14/739927.html (20.08.2017).

- Hormats, R. (2011): The United States' "New Silk Road" Strategy: What is it? Where is it Heading?, U.S. Department of State; Washington, DC, http:// www.state.gov/e/rls/rmk/2011/174800.htm (13.05.2014.).

- Kulintsev, Y. (2015): "One Belt, One Road" - initiative with Chinese characteristics, The Russian International Affairs Council, http://russiancouncil. ru/blogs/riacexperts/?id_4=1868 (20.08.2017).

- Latukhina, K. (2016): Russia, China and Mongolia will create an economic corridor, The Russian Newspaper, https://rg.ru/2016/06/23/rossiia-kitaj-imongoliia-sozdadut-ekonomicheskij-koridor.html (20.08.2017).

- Mosyakov, D. (2014): Chinese politics in the South-China Sea, Perspective, http://www.perspektivy.info/history/na_grani_fola_politika_kitaja_v_ juzhno-kitajskom_more_2014-01-16.htm (20.08.2017).

- Pop, Irina Ionela (2016): Strengths and Challenges of China's "One Belt, One Road" Initiative, Centre for Geopolitics and Security in Realism Studies London, UK.

- Sukhareva, O. (2016): "Silk Road" - unopposed north route, The Ritm of Eurasia, https://www.ritmeurasia.org/news--2016-06-30--shelkovyj-putbezalternativnost-severnogo-marshruta-24422 (20.08.2017).

- Wang, J. (2012): March west: rebalancing China's geostrategy, Global Times, http://opinion.huanqiu.com/opinion_world/2012-10/3193760.html (20.08.2017).

- Wang, Y. (2016): Offensive for defensive: the belt and road initiative and China's new grand strategy, The Pacific Review 29, 455-463.

- Zamaraeva, N. (2017): China-Pakistan economic corridor and position of India, The East Analitica, http://va.ivran.ru/articles?artid=7258 (20.08.2017). 
Pregledni naučni članak Primljen 12.10.2017.

Odobren 17.11.2017.

\section{PRVI REZULTATI SPOLJNE POLITIKE PROCESA IMPLEMENTACIJE NOVOG PROJEKTA - JEDAN POJAS-JEDAN PUT U EUROAZIJI}

U radu se postavlja pitanje koliko je na samom početku efikasna nova kineska strateška inicijativa - Jedan pojas, jedan put. Na osnovu opšteg opisa osnovnih principa i komponenti ove inicijative, autor pokušava da naglasi prednosti i nedostatke potencijalne implementacije, posebno nagašavajući odnos Kine i predloženih partnera. Centralna Azija i Rusija su stoga pod mikroskopom, pošto ove susedne države nemaju drugi način nego da sarađuju sa Kinom kao nedvosmisleno rastućom ekonomskom i geopolitičkom silom. Autor istražuje zajedničke sfere interesovanja Kine i ovih zemalja kada je reč o budućoj zamisli “jednaka saradnja za sve”. Model kineskog ponašanja i kapacitet ove države za dijalog se razmatra putem analize integracionog projekta "EAEU-Silk Road".

Ključne reči: Projekat - Jedan pojas-jedan put (BRI), novi put svile, infrastrukturni projekti, saradnja, Kina. 